\title{
FAKTOR PERILAKU DAN LINGKUNGAN DALAM PEMANFAATAN PELAYANAN KESEHATAN MASYARAKAT
}

\author{
Oleh: \\ WIDA SILVIA \\ Program Studi Kesehatan Masyarakat Universitas Faletehan
}

\section{Pendahuluan}

Fokus pelayanan kesehatan masyarakat lebih bersifat promotif, preventif dan protektif agar frekuensi penyakit berkurang atau tereradikasi dengan melakukan proteksi atau dengan diciptakannya peraturan-peraturan yang mendukung upaya kesehatan (heathy policy). Upaya dengan sasaran masyakat ini antara lain keterlibatan masyarakat agar terjadi perubahan di masyarakat dalam mengatasi suatu masalah kesehatan baik untuk pencegahan dan pengendalian penyakit menular, maupun menekan angka penyakitpenyakit tidak menular.(Notoatmodjo, 2012)

Tantangan kedepan akibat perubahan sosial dan ekonomi menyebabkan pola penyakit menjadi semakin kompleks yaitu selain perubahan alam dan perubahan perilaku yang terbukti tidak hanya dipengaruhi oleh pemahaman individu semata-mata tetapi terbukti berkaitan erat dengan determinan sosial dan budaya.(Notoatmodjo, 2003)

Keterlibatan individu dalam berperilaku sehat pada penyakit kronis (misalnya, berhenti merokok dan penggunaan tembakau, menjadi lebih aktif secara fisik serta makan makanan bergizi), akses pelayanan kesehatan preventif (misalnya, chek up kesehatan rutin, skrining untuk kanker, memeriksa tekanan darah dan kolesterol), dapat menekan angka morbiditas dan mortalitas dari penyakit kronis serta biaya medis yang lebih rendah.

Di era ilmu pengetahuan dan perkembangan teknologi abad sekarang ini, menimbulkan persoalan yang sangat besar berkenaan dengan pencemaran lingkungan. Tanah, air, udara, sedemikian rupa telah tercemar oleh bahan-bahan kimia, pestisida, limbah logam berat, bahan-bahan radiokatif, termasuk konsumsi bahan pengawet makanan dan obatobatan tertentu. Hal ini menjadi pertanyaan besar, sejauh manakah substansi-substansi ini menimbulkan pengaruh merugikan kesehatan manusia. Karena banyak kekhawatiran 
berkaitan dengan efek kesehatan jangka panjang, dengan manifestasi bertahun-tahun setelah seseorang mulia berhubungan dengan faktor eksposure.

\section{Hasil Kajian}

Semakin banyaknya paparan bahan-bahan kimia baru yang mengenai diri kita, menimbulkan persoalan serius tentang bahaya-bahayanya dan mengancam kesehatan tanpa kita sadari. Terkadang bahaya yang tidak disangka baru diketahui setelah terjadi kerusakan cukup besar.

Kualitas air sungai yang tercemar bakteri tinja (total coliform sebesar 2400-9200 MPN/100 ml) ditemukan di sungai Cibanten diperlukan pencegahan dan pengelolaan limbah dimasyarakat.(Hayat \& Kurniatillah, 2021) Kadar Clor bebas melebihi baku mutu lingkungan di Sungai Cidanau.(Hayat, 2020)

Dukungan sosial dengan masalah kesehatan terbagi dalam bentuk dukungan emosional, dukungan penghargaan, dukungan instrumental dan dukungan informatif. Seperti halnya contoh studi diantaranya faktor perilaku dalam penanganan keamanan bahan tambahan makanan seperti formalin.(Hayat \& Darusmini, 2021) melalui praktik pengelolaan limbah yang memenuhi persyaratan kesehatan.(Hayat, 2015) Upaya peningkatan sumber daya manusia melalui peningkatan faktor predisposisi, enabling dan reinforcing.(Hayat, 2012) Juga pentingnya dukungan masyarakat dalam pemanfaatan pelayanan kesehatan.(Hayat, Arifiati, et al., 2021) Pendidikan kesehatan melalui program Cuci Tangan Pakai Sabun (CTPS) di masyarakat.(Hayat, 2021) Edukasi gerakan masyarakat dalam pemberantasan penyakit demam berdarah.(Hayat, Nurdiawati, et al., 2021) Eleminasi penyakit malaria di masyarakat.(Hayat \& Kurniatillah, 2009)

\section{Kesimpulan}

Pemanfatan pelayanan kesehatan dipengaruhi oleh faktor perilaku dan lingkungan dalam pencegahan dan pengendalian masalah kesehatan masyarakat. 


\section{Referensi}

Hayat, F. (2012). Pengaruh predisposing factor, Enable factor, Reinforcing factor terhadap praktik keselamatan kerja pada tenaga kesehatan dalam pengelolaan limbah medis padat di Puskesmas Wilayah Kota Cilegon tahun 2011. In Unpad Repository. Unpad.

Hayat, F. (2015). Analisis faktor pengelolaan limbah medis padat di Rumah Sakit Umum Daerah Kota Cilegon. Faletehan Health Journal, 3, 146-151.

Hayat, F. (2020). Analisis Kadar Klor Bebas (C12) dan Dampaknya Terhadap Kesehatan Masyarakat di Sepanjang Sungai Cidanau Kota Cilegon. Jurnal Kesehatan Masyarakat Mulawarman (JKMM), 2(2), 64-69.

Hayat, F. (2021). THE EFFECT OF EDUCATION USING VIDEO ANIMATION ON ELEMENTARY SCHOOL IN HAND WASHING SKILL. Acitya: Journal of Teaching and Education, 3(1), 44-53.

Hayat, F., Arifiati, N., \& Permatasari, T. A. E. (2021). Peran Dukungan Suami dan Faktor Lainnya terhadap Pemanfaatan Pelayanan Gizi oleh Ibu Hamil dengan Risiko Kurang Energi Kronis (KEK). Jurnal Keperawatan Silampari, 5(1), 125133.

Hayat, F., \& Darusmini, D. (2021). ANALISIS FAKTOR PENGGUNAAN FORMALIN PADA PEDAGANG TAHU DI PASAR TRADISONAL KOTA SERANG. Jurnal Surya Muda, 3(2), 121-132.

Hayat, F., \& Kurniatillah, N. (2009). Situasi Malaria di Kabupaten Lebak. Kesmas: Jurnal Kesehatan Masyarakat Nasional (National Public Health Journal), 3(6), 259-263.

Hayat, F., \& Kurniatillah, N. (2021). Microbiological and Water Quality Status of Cibanten River. The First International Conference on Social Science, Humanity, and Public Health (ICOSHIP 2020), 198-200.

Hayat, F., Nurdiawati, E., \& Kurniatillah, N. (2021). EDUKASI GERAKAN PEMBERANTASAN NYAMUK (PSN) DEMAM BERDARAH PADA ANAK USIA SEKOLAH DASAR DI KECAMATAN JAWILAN KABUPATEN SERANG.

Notoatmodjo, S. (2003). Pendidikan dan perilaku kesehatan.

Notoatmodjo, S. (2012). Promosi kesehatan \& ilmu perilaku. In Jakarta: Rineka Cipta. 
